\title{
RAJYA RAJYA ING JAWA MADHYA, RAJA-RAJA MATARAM KUNA ABAD 9-10 MASEHI: PERBANDINGAN ANTARA NASKAH PUSTAKA RAJYA-RAJYA I BHUMI NUSANTARA DENGAN PRASASTI WANUA TENGAH III
}

\author{
Kayato Hardani \\ (Dinas Tata Ruang Kota Surakarta)
}

\begin{abstract}
Pustaka Rajya Rajya has become a controversial text in Indonesian historiography. Some experts including philologists, archaeologists, and historians are still having strong arguments on the authenticity of the text. Pustaka Rajya are indeed an interesting text to be examined. Among others, Pustaka Rajya told 'a fantastic' story, on the History of Ancient Mataram Kings. In other hand, we also found another authentic historical source, Wanua Tengah III inscription. This copper inscription also contains a 'short story' about ancient Mataram kings. Therefore, in this article informations from the two sources will be compared. The result shows how the 'writer in the past' has written 'his own past'.
\end{abstract}

Key words: Naskah, Teks, Prasasti, perbandingan, Sejarah Kuna, Mataram Kuna

\section{NASKAH DAN TEKS DALAM LINGKUP SASTRA DAN SEJARAH}

"Ketika sastra dan sejarah dibicarakan secara bersama-sama segera muncul pertanyaan, apakah ada fiksi di dalam sejarah dan apakah ada fakta di dalam sastra..."

Kutipan salah satu kalimat dari bab pendahuluan buku "Gagalnya Historiografi Indonesiasentris?!" tulisan Bambang Purwanto (2006) tersebut merupakan titik awal wacana atas dekonstruksi historiografi Indonesia. Sebuah wacana yang ditujukan bagi masyarakat sejarawan Indonesia yang terlampau memuja secara berlebihan tanpa kritik terhadap konstruksi cara berpikir yang telah terbangun. Wacana ini sekaligus menawarkan cara berpikir yang lain dalam rangka memahami dan memaknai masa lalu Indonesia (Purwanto, 2006:2).

Dalam pandangan umum, sastra seringkali dihubungkan dengan fiksi yang imajinatif dan simbolis, bahkan kadangkala terselip unsur irrasional. Di sisi lain, sejarah dipandang sebagai kebalikan dari fiksi yakni bertutur tentang realitas. Untuk menemukan kebenaran masa lalu hingga pada tataran praktis antara fakta dan fiksi pada dasarnya tidak ada 
perbedaan yang berarti secara tekstual. Sejarah dan sastra dapat diasosiasikan dalam bidang yang sama yakni bahasa (Purwanto, 2006:3).

Salah satu bentuk karya sastra yang "bemafaskan" sejarah adalah serat, babad atau juga pustaka. Berbagai dokumen yang berbentuk karya sastra tersebut dapat dipakai sebagai alat untuk memahami berbagai pola perilaku kesejarahan dari masyarakat penganutnya. Dalam konteks ini karya sastra telah menjadi bagian yang integral dengan sejarah suatu tradisi (Purwanto, 2006:97). Sebagai bentuk tradisi karya sastra memiliki 4 fungsi yakni,

1) sebagai alat dokumentasi

2) sebagai media untuk mentransfer memori masa lalu antar generasi

3) sebagai alat untuk membangun legitimasi

4) sebagai bentuk ekspresi intelektual

Meski demikian, berbagai karya-karya tersebut oleh sebagian besar sejarawan dianggap sebagai karya sastra yang hanya memuat cerita fiktif dan tidak ada hubungannya dengan sejarah yang merupakan rekonstruksi atas fakta dan realitas empirik masa lalu (Purwanto, 2006:95). Meski demikian karya-karya tersebut tetap dapat dijadikan pertimbangan penulisan sejarah kebudayaan kuna. Asumsinya, ketika para pengarang menulis karyanya, tentu ia telah melakukan observasi pada lingkungan sekitarnya. Kondisi sosial, budaya,dan politik direkam untuk kemudian diparafrasekan menjadi karya tulisan sesuai dengan persepsinya. Namun, dengan terlampau mengandalkan karya sastra sebagai sumber historis justru banyak menimbulkan bias, sehingga diperlukan data pendukung dari suatu sumber lain yang tidak ada hubungan kepentingan dengan sumbersumber tersebut. Bahkan seringkali suatu "teks" akan muncul dalam beberapa "naskah" dengan wajah yang berbeda-beda.

Dalam studi filologi, kata "naskah" hampir selalu dikaitkan dengan kata "teks", bahkan tidak jarang kedua istilah itu dirancukan meski pada hakikatnya kedua istilah tersebut mempunyai perbedaan yang signifikan. Sudibyo (1999) mengidentifikasikan perbedaan antara "teks" dan "naskah". Teks berasal dari bahasa latin textus atau textum yang diturunkan dari verba texere yang berarti menenun atau menganyam. Teks adalah sebuah metafora yang melihat keseluruhan kompleks wacana sebagai suatu anyaman atau tenunan. Teks adalah sebagai tenunan atau anyaman katakata yang membangun suatu karya dan yang disusun dengan suatu cara tertentu untuk menciptakan arti yang mantap dan unik. Teks ditinjau dari sudut pandang epistemologis merupakan bagian dari suatu perangkat konseptual yang berpusat pada tanda. Tanda adalah suatu konsep historis, suatu artefak analitis, atau suatu artefak ideologis.

Naskah adalah objek yang sudah selesai dan mewujud secara fisik, misalnya melalui buku atau kitab, sedangkan teks adalah suatu medan metodologis yang tidak pernah final. Teks menampakkan dirinya, menurut suatu aturan tertentu dan dialami hanya melalui suatu aktivitas atau produksi. Ini berarti bahwa teks tidak dapat berhenti hanya pada bentuk fisik yang memanifestasikannya, baik berupa naskah maupun buku. Teks adalah 
lintasan yang dapat menembus ruang dan waktu. Dengan sendirinya, teks dapat melintasi naskah atau banyak naskah. Berdasar pada hal-hal di atas, teks tidak perlu lagi dikacaukan dengan naskah.

Munculnya penyalinan teks dalam sejumlah naskah jamak dijumpai di dalam tradisi tulis. Penulisan ulang seringkali dijumpai modifikasimodifikasi berupa penambahan atau penghilangan. Penulisan ulang selain ditemukan dalam naskah sastra juga dijumpai di dalam prasasti seperti munculnya prasasti-prasasti tinulad yang ditulis ulang jauh di masa sesudah prasasti yang disalin. Cukup banyak prasasti tinulad semacam ini. Penyalinan ulang ini kadangkala tidak lagi berperan sebagai penyalin dalam arti yang sesungguhnya, penyalin-penyalin ini banyak berperan sebagai pengarang kedua (Soeratno,1994:6). Hal ini menyebabkan teks-teks yang sampai kepada kita di masa kini tidak dalam bentuk asalnya sebagaimana yang diciptakan (dituliskan) pengarang. Hal tersebut sangat mempengaruhi biasnya data sejarah yang kemungkinan tersurat di dalam naskah. Secara umum penyalinan ulang disebabkan oleh beberapa hal.

1. Adanya keinginan yang kuat untuk menyebarkan informasi yang terkandung dalam teks yang dipandang penting sehingga menyebabkan teks perlu ditransmisikan.

2. Di dalam perjalanannya teks telah melintasi batas ruang dan waktu yang berakibat teks rentan terhadap perubahan. Perubahan ini terutama disebabkan oleh persepsi dan interpretasi dalam proses transmisi dengan tujuan menyesuaikan salinan dengan suatu kondisi tertentu.

3. Teks sendiri kadang-kadang memuat himbauan agar dirinya direnovasi, dikoreksi, dan disempurnakan.

4. Adakalanya dalam proses transmisi dipergunakan referensi yang pada akhirnya menyebabkan terjadinya percampuran tradisi (Sudibyo, 1999)

Dari keempat alasan tersebut setidaknya masih terdapat alasan lain yang lebih sering dijumpai di dalam penyalinan ulang suatu prasasti, yakni berkaitan dengan legitimasi suatu keputusan yang telah ditetapkan di masa lalu. Oleh penyalin, prasasti lama dikutip sebagai landasan formal penguat ditetapkannya keputusan yang baru terbit untuk kemudian dituliskan kembali di media penulisan yang baru. Di dalam penyalinan ulang prasasti tersebut pada dasarnya sang penyalin sudah mengetahui bahwa mengubah isi prasasti adalah terlarang karena di dalam prasasti sendiri sudah menyatakan kutukan bagi yang mengubah ketetapan raja yang telah ditulis dalam prasasti.

Fenomena salin ulang inilah sepertinya samar-samar teramati di dalam naskah Pustaka Rajya Rajya (selanjutnya disebut sebagai PRRBN) dan prasasti Wanua Tengah III (selanjutnya disebut sebagai WT III). Keduanya sama-sama menceritakan masa lalu dengan rinci dan runtut atas suatu peristiwa yang tidak semasa dengan waktu penulisannya. Ditengarai keduanya menyalin dari sumber tertulis lain yang lebih tua.

Antara PRRBN dan WT III akan dicoba "dibicarakan secara bersama-sama" yakni sebagai naskah sastra dengan naskah sejarah "otentik". Di dalam kedua naskah tersebut terdapat sepenggal "cerita" 
bertema sama yakni pada penyebutan raja-raja Mataram kuna yang berkuasa di Jawa Tengah pada abad ke 9-10 Masehi. Kesamaan tersebut dijumpai dalam nama tokoh, tahun penobatan hingga tahun-tahun pergantian tahta, bahkan alur genealogis. Kisah masa lalu dari kerajaankerajaan kuna beserta raja yang pemah bertahta menempati tema yang strategis untuk ditulis dalam naskah. Tercatat sejumlah naskah yang bertema demikian, di antaranya Pararaton yang ditulis pada masa Singhasari, naskah Babad Tanah Jawi dari masa Surakarta (abad ke-17), Bujangga Manik (abad ke-16) serta naskah Pustaka Rajya-Rajya i Bhumi Nusantara dari masa Cirebon. Pengambilan tema sentral tentang raja-raja tersebut dapat dikaitkan dengan fungsi naskah sebagai media legitimasi, baik secara genealogis maupun politis.

Hingga saat ini rekonstruksi sejarah kuna Indonesia (baca: Mataram Kuna) abad ke-8 - 10 Masehi masih bersandar pada interpretasi yang diperoleh dari muatan historis WT III. Prasasti tembaga ini diyakini sebagai satu-satunya bukti otentik mengenai keberadaan 13 raja yang pernah berkuasa di Mataram Kuna dari kurun waktu tersebut, yakni pada masa Dyah Balitung sebagai tokoh penerbit prasasti. Meski demikian, WT III sendiri sepertinya juga menggunakan acuan naskah lain yang kemudian dipakai untuk mendeskripsikan keputusan raja-raja terdahulu sebelum Dyah Balitung, dalam hal penetapan atau pencabutan kedudukan sawah sima di bihara Pikatan. Karena kita menjumpai ada keterpautan waktu hingga 162 tahun antara raja pertama yang disebut yakni Sanjaya (di dalam WT III ditulis sebagai Rahyangta i Mdang) hingga raja terakhir yang disebut yakni Dyah Balitung. Selain itu, penyalinan juga terlihat di dalam WT III pada pernyataan "... nahan praśasti rake garung... " yang berarti "demikianlah prasasti rake Garung". Pemyataan ini jelas menyalin secara utuh dari prasasti masa raja Garung yang berbahasa Sanskerta.

Penyebutan nama-nama raja di dalam WT III tersebut dapat diklasifikasikan sebagai "penulisan sejarah secara sekunder". Artinya, menyalin dari suatu sumber acuan lain untuk kemudian dipahatkan di atas logam tembaga dan akhimya menjadi abadi hingga sampai ke tangan kita di masa kini. Meski diyakini benar jika sebelum prasasti dituliskan pada media logam terlebih dahulu dituliskan pada selembar naskah daun (ikitha patra).

\section{POLEMIK PRRBN}

PRRBN ditulis dalam bentuk prosa yang mendeskripsikan sejarah Jawa dari masa prasejarah hingga masa sebelum kedatangan Eropa secara "logis" yakni tanpa adanya unsur-unsur mistis layaknya naskah yang ditulis pada masa pra-abad ke-20. ${ }^{1}$ Dapat dikatakan jika PRRBN adalah sebuah

Secara sederhana dapat diperbandingkan dengan asal muasal raja-raja. Di dalam PRRBN sejarah raja-raja Jawa bermula dari masa yang kacau di India pada masa dinasti Saka. Sebagian dari kalangan raja bermigrasi keluar India. 
"naskah sejarah" yang dicirikan dengan alam pikir rasional. PRRBN merupakan salah satu bagian dari naskah Wangsakerta yang terdiri dari 5 seri karangan yang masing-masing berjudul carita parahyangan, negarakrtabhumi, pustaka dwipantarapanwa, pustaka pararatwan i bhumi jawadwipa dan pustaka rajya rajya i bhumi nusantara. Naskah wangsakerta dianggap sebagai karya "sastra sejarah kontroversial" bahkan "palsu" yang dibuat beberapa belas abad setelah terjadinya peristiwa yang dituliskan. Hal inilah yang menimbulkan dua kubu yang saling bertolak belakang yakni pro dan kontra.

Ditemukannya naskah Wangsakerta pada awal tahun 1970-an telah menimbulkan kegembiraan dan kekaguman akan kelengkapannya. Namun di lain pihak justru menimbulkan polemik, bahkan ada pihak yang menduga bahwa naskah ini aspal (asli tapi palsu). Naskah PRRBN juga dianggap memiliki nilai kesahihan "lebih rendah" dibanding naskah-naskah lain seperti Pararaton dan Negarakrtagama. Beberapa hal yang menyebabkan PRRBN diperlakukan sedemikian antara lain karena,

1. Terlalu historis, isinya tidak umum sebagaimana naskah-naskah sezaman (babad, kidung, tambo, hikayat);

2. Cocoknya isi naskah dengan karya-karya sarjana Barat (J.G. de Casparis, N.J. Krom), sehingga ada dugaan bahwa naskah ini disusun dengan merujuk pada karya para ahli tersebut (tidak dibuat abad ke-17);

3. Keadaan fisik naskah (kertas/daluang, tinta, bentuk aksara) menunjukkan naskah yang dijadikan rujukan merupakan salinan dan tulisannya kasar, tidak seperti naskah lama pada umumnya.

Nina $\mathrm{H}$. Lubis di dalam makalahnya dengan berani mengambil kesimpulan jika naskah Wangsakerta tidak layak dijadikan acuan sebagai sumber sejarah meski demikian tetap layak dijadikan sebagai kajian filologi (Lubis, 2002: 25).

Sementara itu, pihak yang mendukung terhadap keaslian naskah Wangsakerta berpandangan bahwa naskah tersebut memiliki keunikan yang menyangkut soal cara dan prosedur penyusunan, cara dan bentuk penyajian, serta materi yang dikemukakan mengandung ciri-ciri historiografi modem. Berikut adalah pendapat Edi Ekadjati mengenai hal tersebut (2005b:225).

1. PRRBN disusun secara sadar dan dikemukakan secara tersurat sebagai karangan yang merupakan karya tulis sejarah. Di dalamnya pengarang ingin mencari dan menemukan kebenaran sejarah yakni kebenaran mengenai peristiwa yang terjadi di masa lampau.

2. PRRBN disajikan dengan bahasa dan dalam bentuk kisah yang mendekati sistematis, kronologis dan menggunakan alam pikiran logis.

Sedangkan di dalam Babad Tanah Jawi, sejarah raja-raja Jawa bermula dari Nabi Adam yang menurunkan sejumlah tokoh-tokoh Hindu dan pewayangan yang pada akhirnya menurunkan asalsilah raja-raja Jawa. 
3. Secara sadar dan tersurat dikemukakan proses dan prosedur penyusunan PRRBN yang merupakan bentuk pertanggungjawaban dari penyusunnya.

4. Secara konsisten karangan itu disusun secara teratur yakni setiap sargah terdiri dari atas pendahuluan, inti karangan dan penutup.

5. Inti karangan disebutkan raja-raja yang memerintah di suatu kerajaan yang dikemukakan secara konvensional serta peristiwa-peristiwa tertentu yang dilengkapi dengan angka-angka tahun dalam sistem kalender Saka.

Meski demikian Ekadjati masih menampakkan gambaran dilematis mengenai penilaian atas naskah Pangeran Wangsakerta yakni dari segi fisik, apakah naskah tersebut merupakan naskah asli yang ditulis oleh tim Pangeran Wangsakerta atau naskah salinan. Apabila salinan, naskah ini merupakan salinan ke berapa. Kemudian dari segi isi, bagaimanakah mungkin pengarang teks naskah ini mengetahui keadaan zaman prasejarah dan awal sejarah Nusantara karena jarak waktu yang terlampau jauh, meski di sargah terakhir disebut adanya sumber-sumber sebanyak lebih dari 1500 literatur (Ekadjati,2005a:241).

\section{PRRBN 2.4 DAN WT III: KRITIK INTERN}

Informasi pertama kali tentang keberadaan naskah Pangeran Wangsakerta tertera pada naskah Carita Purwaka Caruban Nagari yang ditemukan tahun 1970 di daerah Indramayu. Carita Purwaka Caruban Nagarai disusun oleh Pangeran Arya Carbon pada tahun 1720. Di akhir teks naskah tersebut dikatakan bahwa isi naskah disusun berdasarkan teks yang terdapat dalam naskah Negarakretabhumi ... sinangggurit miturut kitab nagarakrtabhumi... Naskah Negarakrtabhumi sendiri adalah salah satu seri dari naskah Pangeran Wangsakerta (Ekadjati, 2005a:237). Penemuan kembali naskah Wangsakerta ini diawali pada tahun 1977 ketika kepala Museum Sri Baduga melakukan pembelian naskah dari seorang perantara bernama Mohamad Asikin. Meskipun diketahui bahwa naskah ini pada tahun 1926-1931 terpisah-pisah menjadi beberapa bagian yang tersebar di Palembang, Serang dan Jambi (Ekadjati: 2005c, 262)

PRRBN ditulis oleh tim di bawah pimpinan Pangeran Wangsakerta (putra Panembahan Girilaya yang berkuasa di Cirebon pada tahun 16501662) yang diselesaikan pada tahun 1698 (Ayatrohaedi, 1991:30). Di dalam naskah ini disebutkan bahwa karya tersebut merupakan hasil gotrasawala (seminar) yang diselenggarakan di Cirebon dengan mengundang tim peneliti dari berbagai daerah. Disebutkan juga setiap daerah mengirimkan 70 orang utusan.

Tiap naskah Pangeran Wangsakerta memiliki ukuran yang sama yakni sekitar $27,5 \times 32,5 \mathrm{~cm}$. Bagian yang ditulisi berukuran $22,3 \times 32,5 \mathrm{~cm}$, kecuali halaman pertama dan halaman terakhir, untuk sebagian besar digaris rangkap persegi dengan dua garis sejajar jarak rata-rata $1 \mathrm{~cm}$. Pada 
halaman pertama dan terakhir garis paling luar diberi lukisan sekelilingnya. Banyaknya tulisan pada setiap halaman ialah 21 atau 22 larik, tinggi aksara $\pm 5 \mathrm{~mm}$ (Atja, 2005:179). Naskah ini ditulis di atas kertas daluang dengan tinta hitam. Aksara dan bahasa yang dipergunakan tergolong aksara dan bahasa Jawa Pesisiran yang di dalamnya banyak mengandung kosakata Jawa Kuna (Lubis, 2002;21). Untuk naskah PRRBN 2.4 telah selesai disunting secara filologis di tahun 1991 oleh Atja dan Ayatrohaedi.

WT III ditemukan di bulan November 1983 di dusun Dunglo, desa Gandulan, Kecamatan Kaloran, Kabupaten Temanggung, Jawa Tengah. Prasasti terdiri dari dua lempeng tembaga berukuran $23,5 \times 52,5 \mathrm{~cm}$ (lempeng I) dan $25,5 \times 55,5 \mathrm{~cm}$ (lempeng II). Lempeng I berisi 17 baris tulisan pada satu sisi dan lempeng II berisi 26 baris tulisan pada sisi depan dan 18 baris tulisan pada sisi belakang (Dwiyanto, 1986:95). Secara umum prasasti berisi tentang riwayat perubahan status sawah di Wanua Tengah dari masa Panangkaran hingga Balitung. Dengan penemuan prasasti ini banyak bagian dari rekonstruksi sejarah Jawa Kuna ditinjau ulang, karena ada tokoh-tokoh raja yang sebelumnya tidak diketahui dan belum pernah dijumpai di prasasti lain. Meski demikian nilai kesahihan prasasti ini cukup tinggi, dibuktikan dengan banyaknya kesesuaian isi dengan prasastiprasasti lain terutama dalam hal nama tokoh.

Baik WT III dan PRRBN dapat didudukkan sebagai sumber sekunder dalam "penulisan sejarah" (khususnya raja-raja Mataram Kuna), yakni ada keterpisahan antara sejarah yang ditulis dengan waktu penulisannya. Meskipun demikian, sumber sekunder dapat dipergunakan sebagai sumber bila sumber primer tidak ada, dengan catatan, untuk memperoleh fakta (bukan data) harus dilakukan prosedur koroborasi, yaitu pendukungan suatu data dari sumber dengan data lain yang berasal dari sumber lain, yang tidak ada hubungan kepentingan di antara sumbersumber itu atau kedudukan sumber itu bebas (merdeka). Dukungan dari berbagai sumber yang merdeka bisa menghasilkan fakta yang mendekati kepastian (certainy fact), sedangkan bila dukungan kurang, mungkin fakta yang dihasilkan hanya sebatas dugaan (alleged fact). Bila koroborasi tidak bisa dilakukan karena ketiadaan data atau sumber lain, nilai sumber itu, baik sumber primer ataupun sekunder dianggap sebagai pembuktian sejarah yang lemah (Garraghan, 1946 dalam Lubis 2002).

Untuk itu di dalam tulisan ini pembahasan masalah hanya dibatasi pada perbandingan untuk mencari perbedaan dan persaman antar keduanya, yakni dengan jalan membandingkan naskah PRRBN 2.4 dengan WT III khususnya pada penggal cerita mengenai raja-raja Mataram Kuna abad ke 8-10 Masehi yakni semenjak Sanjaya hingga Balitung. Selain itu juga digunakan sejumlah prasasti lain yang memiliki relevansi dengan raja Mataram kuna. 
Di dalam pembukaan PRRBN 1.1 disebutkan bahwa penulisan naskah ini dimaksudkan sebagai bhrehatkatha. Istilah bhrehatkatha atau secara etimologi bermakna kumpulan riwayat. Tidak seperti umumnya prasasti yang dimulai dengan formula pertanggalan swasti sakawarsatita "selamat, tahun Saka telah berlalu", WT III dibuka dengan kata wuara yang tidak lain sebagai pembuka cerita.

Dari pembacaan transkripsi dan transliterasi PRRBN 2.4 khususnya pada bagian raja-raja Mataram kuna (Jawa Tengah) yang ditulis sebagai mangene kacakrawartyan raja-raja ing jawa madhya, tokoh Sanjaya terlihat mendapat proporsi yang sangat besar dibanding tokoh-tokoh raja lainnya bahkan cenderung diulang-ulang di bagian yang berbeda. Cerita mengenai diri Sanjaya terasa lebih lengkap dibanding raja lain. la dikisahkan mulai ketika masa kecil, keberadaan kedua orang tuanya, sebagai raja muda, peperangan yang dilakukan hingga anak dan kedua istrinya. Setidaknya dijumpai 11 kali penyebutan tentang tokoh Sanjaya. Menariknya PRRBN 2.4 justru tidak menyebutkan kapan dan dimana Sanjaya wafat mengingat proporsi kisah masa jaya sangat besar. Setelah itu tokoh raja yang mendapat proporsi cukup banyak adalah Panangkaran sebanyak 5 kali. Berturut-turut Rakai Warak, Garung, Pikatan dan Kayuwangi hanya disebutkan sebanyak 2 kali di dalam keseluruhan naskah, sedangkan tokoh raja Rakai Gurunwangi, Watumalang dan Balitung hanya disebut 1 kali. Tentunya ada latar belakang penulisan yang patut ditelusuri mengenai hal semacam ini.

Uraian raja-raja Mataram Kuna (Sanjaya hingga Balitung) dalam PRRBN 2.4 secara berurutan dan sistematis ditemukan pada halaman naskah 101 sampai dengan 108. Untuk WT III ditemukan pada lempeng I baris 1 sampai dengan 17 dan lempeng Ila dari baris 1 hingga 6 . Sebagai pembanding disertakan pula daftar raja yang terdapat dalam prasasti Mantyasih I. Berikut adalah tabel komparasi nama raja-raja yang dijumpai dalam ketiga naskah tersebut. 


\begin{tabular}{|c|c|c|c|c|c|c|c|}
\hline & $\begin{array}{l}\text { NAMA RAJA } \\
\text { (PRRBN 2.4) }\end{array}$ & $\begin{array}{c}\text { TAHUN } \\
\text { BERKUASA } \\
\text { (SAKA) }\end{array}$ & & $\begin{array}{l}\text { NAMA RAJA } \\
\text { (WT III) }\end{array}$ & $\begin{array}{l}\text { TAHUN } \\
\text { BERKUASA } \\
\text { (SAKA) }\end{array}$ & & $\begin{array}{l}\text { NAMA RAJA } \\
\text { MANTYASIH I) }\end{array}$ \\
\hline 1. & Rakai Sanjaya & $634-676$ & 1. & $\begin{array}{l}\text { Rahyangta ri } \\
\text { Mdang }\end{array}$ & & 1. & $\begin{array}{l}\text { Rakai Mataram } \\
\text { Sang Ratu } \\
\text { Sanjaya }\end{array}$ \\
\hline 2. & $\begin{array}{l}\text { Rakai Panangkaran/Sri } \\
\text { Maharaja Tejahpurnapana } \\
\text { Panangkarana/Dyah } \\
\text { Sangkara }\end{array}$ & $676-704$ & 2 & $\begin{array}{l}\text { Rake } \\
\text { Panangkaran }\end{array}$ & $668-706$ & 2. & $\begin{array}{l}\text { Sri Maharaja } \\
\text { Rakai } \\
\text { Panangkaran }\end{array}$ \\
\hline 3. & $\begin{array}{l}\text { Rakai Panunggalan/Haji } \\
\text { Rakai Panunggalan } \\
\text { Lingganagarotama/Prabu } \\
\text { Dyah Panunggalan } \\
\text { Bimaparakrama } \\
\text { Linggapawitra } \\
\text { Yawabhumandala } \\
\end{array}$ & $704-722$ & 3. & Rake Panaraban & $706-725$ & 3. & $\begin{array}{l}\text { Sri Maharaja } \\
\text { Rakai } \\
\text { Panunggalan }\end{array}$ \\
\hline 4. & $\begin{array}{l}\text { Sri Maharaja } \\
\text { Wirawairimattama/ Sang } \\
\text { Dharanindra }\end{array}$ & $704-719$ & 4. & & & 4. & \\
\hline 5. & $\begin{array}{l}\text { Sri Maharaja } \\
\text { Samaratungga/ } \\
\text { Samaragrawira }\end{array}$ & $719-764$ & 5. & & & 5. & \\
\hline 6. & $\begin{array}{l}\text { Sri Maharani } \\
\text { Pramodhawardhani \& } \\
\text { Rakai Pikatan }\end{array}$ & $764-\ldots$ & 6. & & & 6. & \\
\hline 7. & $\begin{array}{l}\text { Rakai Warak/Dyah } \\
\text { Watukura/Haji Warak } \\
\text { Linggottama Satya } \\
\text { Jayabhumi }\end{array}$ & $722-741$ & 7. & $\begin{array}{l}\text { Rake Warak Dyah } \\
\text { Manara }\end{array}$ & $725-749$ & 7. & $\begin{array}{l}\text { Sri Maharaja } \\
\text { Rakai Warak }\end{array}$ \\
\hline 8. & & & 8. & Dyah Gula & $749-750$ & 8. & \\
\hline
\end{tabular}

Berkala Arkeologi Tahun XXXX Edisi No. 1 / Mei 2010 


\begin{tabular}{|c|c|c|c|c|c|c|c|}
\hline 9. & $\begin{array}{l}\text { Rakai Garung/Dang } \\
\text { Karayan Patapan Pu } \\
\text { Palar }\end{array}$ & $741-762$ & 9. & Rake Garung & $750-768$ & 9. & $\begin{array}{l}\text { Sri Maharaja } \\
\text { Rakai Garung }\end{array}$ \\
\hline 10 & $\begin{array}{l}\text { Sang Pikatan/Dyah } \\
\text { Kamulyan/Sang Prabhu } \\
\text { Linggeswara } \\
\text { Sakalabhumandala }\end{array}$ & $762-778$ & 10 & $\begin{array}{l}\text { Rake Pikatan } \\
\text { Dyah Saladu }\end{array}$ & $768-777$ & 10 & $\begin{array}{l}\text { Sri Maharaja } \\
\text { Rakai Pikatan }\end{array}$ \\
\hline 11 & $\begin{array}{l}\text { Rakai Kayuwangi/Dyah } \\
\text { Lokapala/Sri maharaja } \\
\text { Kayuwangi tunggal } \\
\text { kawasa Sakalabbhumi/Sri } \\
\text { Maharaja Rakai } \\
\text { kayuwangi Sri } \\
\text { Sajjanotsawatungga } \\
\end{array}$ & $778-808$ & 11 & $\begin{array}{l}\text { Rake Kayuwangi } \\
\text { Dyah Lokapala }\end{array}$ & 777 & 11 & $\begin{array}{l}\text { Sri Maharaja } \\
\text { Rakai } \\
\text { Kayuwangi }\end{array}$ \\
\hline 12 & & & 12 & Dyah Tagwas & 806 & 12 & \\
\hline 13 & & & 13 & $\begin{array}{l}\text { Rake } \\
\text { Panumwangan } \\
\text { Dyah Dewendra }\end{array}$ & 807 & 13 & \\
\hline \multirow[t]{2}{*}{14} & \multirow{2}{*}{$\begin{array}{l}\text { Rani Gurunwangi Dyah } \\
\text { Saladu \& Rakai } \\
\text { Gurunwangi Dyah } \\
\text { Ranumanggala }\end{array}$} & \multirow[t]{2}{*}{$808-812$} & 14 & $\begin{array}{l}\text { Rake Gurunwangi } \\
\text { Dyah Bhadra }\end{array}$ & 808 & \multirow[t]{2}{*}{14} & \\
\hline & & & \multicolumn{3}{|c|}{ INTEREGNUM 7 TAHUN } & & \\
\hline 15 & Rakai Watumalang & $818-820$ & 15 & $\begin{array}{l}\text { Rake } \\
\text { Wungkalhumalang } \\
\text { Dyah Jbang }\end{array}$ & $816-820$ & 15 & $\begin{array}{l}\text { Sri Maharaja } \\
\text { Rakai } \\
\text { Watuhumalang }\end{array}$ \\
\hline 16 & $\begin{array}{l}\text { Rakai Watukura Dyah } \\
\text { Balitung/Sri Maharaja } \\
\text { Iswarakesawotsawatungg } \\
\text { a/Sri Dharmodaya } \\
\text { mahasambhu }\end{array}$ & $820-832$ & $\begin{array}{l}16 \\
\cdot\end{array}$ & $\begin{array}{l}\text { Rake Watukura } \\
\text { Dyah Balitung Sri } \\
\text { Iswarakesawotsaw } \\
\text { atungga rudramurti }\end{array}$ & 820 & $\begin{array}{l}16 \\
.\end{array}$ & $\begin{array}{l}\text { Sri Maharaja } \\
\text { Rakai Watukura } \\
\text { Dyah Balitung }\end{array}$ \\
\hline
\end{tabular}

Tabel 1. Perbandingan daftar raja antara PRRBN, WT III dan prasasti Mantyasih I

Berkafa Arkeologi Tahun XXXX Edisi No. 1 / Mei 2010 


\section{SEJUMLAH PERBEDAAN}

Dari tabel perbandingan antara PRRBN 2.4 dengan WT III dan Mantyasih I sebagai data pendukung diperoleh beberapa simpulan perbedaan

\section{Perbedaan angka tahun}

Satu hal yang menarik dari perbandingan dua naskah ini adalah dituliskannya angka tahun (pertanggalan) di dalamnya. Angka tahun tersebut adalah deskripsi nyata masa berkuasanya seorang tokoh raja. Penulisan pertanggalan di WT III lebih lengkap dibanding PRRBN karena memuat hingga satuan hari pasaran (sadwara, pancawara, dan saptawara), sedangkan di PRRBN hanya sebatas angka tahun saja. Diyakini WT III juga menggunakan naskah lain sebagai sumber acuan untuk dikutip. Hal ini didasarkan lengkapnya pertanggalan atas berbagai peristiwa penting yang terjadi di dalam kerajaan selama hampir 162 tahun sebelum Balitung berkuasa, yakni berbagai peristiwa suksesi pemerintahan.

Untuk mengetahui kesahihan pertanggalan yang ditulis di dalam WT III perlu dilakukan perbandingan dengan sumber lain yang sejenis yakni prasasti. Perbandingan tersebut berupa penghitungan berdasar hari pasaran (sadwara, pancawara dan saptawara) pertanggalan di WT III yang diurutkan dengan prasasti lain yang masih dalam satu angka tahun. Dari hasil pengurutan tersebut diperoleh 4 pertanggalan dalam WT III yang dapat dibandingkan dengan prasasti lain yakni:

- Pertanggalan ketika Dyah Gula naik tahta pada 749 srawanamasa caturdasi krsna wa pa su wara yang diteruskan dengan prasasti Gandasuli I yang berpenanggalan kurang lebih 2 bulan lebih awal yakni pada 749 jyestamasa tithi astami suklapaksa wagai wara ..hri (?) pahing (?)

Namun dari transkripsi prasasti Gandasuli I, pertanggalan tersebut sangat meragukan karena menyebutkan pancawara sebanyak dua kali yakni wagai dan pahing, sehingga perbandingan tidak dapat dilakukan.

- Pertanggalan mengenai wafatnya Rakai Wungkal Humalang yang bersamaan naik tahtanya Rakai Watukura Dyah Balitung pada $\mathbf{8 2 0}$ jyestamasa tithi pratipada krsna tu po bu wara yang diteruskan dengan prasasti Penampihan yang berpenanggalan kurang lebih 4 bulan lebih awal yakni pada $\mathbf{8 2 0}$ kartikamasa tithi pancadasi sukla paksa pa wa wo (?) wara.

Prasasti Penampihan sendiri merupakan prasasti tinulad (salinan) yang masih diragukan transkripsinya, sehingga perbandingan tidak dapat dilakukan.

- Pertanggalan ketika Rake Gurunwangi Dyah Bhadra naik tahta pada 808 maghamasa pancami krsna wa po bu wara yang diteruskan dengan prasasti Munggu Antan yang berpenanggalan 23 hari sesudahnya yakni pada 808 phalgunamasa trayodasi suklapaksa wurukung kaliwuan brhaspati wara. 
- Dari tabel pengurutan pertanggalan dua naskah tersebut terdapat selisih 1 hari, berikut adalah tabel pengurutan tersebut.

\begin{tabular}{|c|c|}
\hline $\begin{array}{c}\text { Maghamasa } 808 \\
\text { (WT III) }\end{array}$ & $\begin{array}{c}\text { Phalgunamasa } 808 \\
\text { (Munggu Antan) }\end{array}$ \\
\hline \multicolumn{2}{|c|}{ Suklapaksa } \\
\hline & 1. pawa a \\
\hline & 2. wa ka so \\
\hline & 3. ma u ang \\
\hline & 4. tu pa bu \\
\hline & 5. ha po wr \\
\hline & 6. wu wa su \\
\hline & 7. paka sa \\
\hline & 8. wa u a \\
\hline & 9. ma pa so \\
\hline & 10. tu po ang \\
\hline & 11. hawabu \\
\hline & 12. wu ka wr \\
\hline & 13. pa u su \\
\hline & 14. \\
\hline & 15. \\
\hline \multicolumn{2}{|c|}{ Krsnapaksa } \\
\hline 1. & \\
\hline 2. & \\
\hline 3. & \\
\hline 4. & \\
\hline 5. wa po bu & \\
\hline 6. mawa wr & \\
\hline 7. tu ka su & \\
\hline 8. ha u sa & \\
\hline 9. wu pa a & \\
\hline 10. pa po so & \\
\hline 11. wa wa ang & \\
\hline 12. maka bu & \\
\hline 13. tu u wr & \\
\hline 14. ha pa su & \\
\hline 15. wu po sa & \\
\hline
\end{tabular}

Tabel 2. Penanggalan prasasti Munggu Antan dan WT III

Pada tabel tersebut terlihat terdapat selisih 1 hari pada prasasti Munggu Antan, jika kita menganggap benar atas pertanggalan naik tahtanya Rake Gurunwangi sebagaimana ditulis dalam WT III, maka seharusnya pertanggalan dalam prasasti Munggu Antan hari pasaran jatuh pada wu ka $w r$ bukan hari ke-13 melainkan hari ke-12. Meski demikian selisih yang hanya 1 hari tidak begitu menjadi masalah karena tiap 63 hari 
dalam pertanggalan Jawa Kuna terdapat 1 hari pengurangan (ngunalatri) (Wuryantoro, 1995:173).

- Pertanggalan ketika turunnya perintah Dyah Balitung untuk peswatantra-an seluruh biara di Jawa pada $\mathbf{8 2 6}$ marggasira masa tithi dwitiya suklapaksa wu u so wara yang diteruskan dengan pertanggalan pada prasasti Rumwiga I yang bertaut 47 hari sesudahnya yakni pada 826 posyamasa tithi tritiya krsnapaksa tu pa su wara.

- Dari tabel pengurutan pertanggalan dua naskah tersebut terlihat jika pertanggalan cocok.

\begin{tabular}{|c|c|}
\hline $\begin{array}{c}\text { Marggasira } 826 \\
\text { (WT III) }\end{array}$ & $\begin{array}{c}\text { Posyamasa } 826 \\
\text { (Rumwiga I) }\end{array}$ \\
\hline \multicolumn{2}{|c|}{ Suklapaksa } \\
\hline 1. & 1. ha ka ang \\
\hline 2. wu u so & 2. $w u$ u bu \\
\hline 3. pa pa ang & 3. pa pa wr \\
\hline 4. wa pobu & 4. wa posu \\
\hline 5. ma wa wr & 5. ma wa sa \\
\hline 6. tu ka su & 6. tu ka a \\
\hline 7. hau sa & 7. ha u so \\
\hline 8. wupa a & 8. wu pa ang \\
\hline 9. paposo & 9. pa po bu \\
\hline 10. wa wa ang & 10. wa wa wr \\
\hline 11. ma ka bu & 11. maka su \\
\hline 12. tu u wr & 12. tu u sa \\
\hline 13. ha pa su & 13. hapa \\
\hline 14. wu po sa & 14. wu po so \\
\hline 15. pawa a & 15. pa wa ang \\
\hline \multicolumn{2}{|c|}{ Krsnapaksa } \\
\hline 1.wa ka so & 1. wa ka bu \\
\hline 2. ma u ang & 2. ma u wr \\
\hline 3. tu pabu & 3. tu pa su \\
\hline \multicolumn{2}{|l|}{ 4. ha powr } \\
\hline \multicolumn{2}{|l|}{ 5. wu wa su } \\
\hline \multicolumn{2}{|l|}{ 6. paka sa } \\
\hline \multicolumn{2}{|l|}{ 7. waua } \\
\hline \multicolumn{2}{|l|}{ 8. ma pa so } \\
\hline \multicolumn{2}{|l|}{ 9. tu po ang } \\
\hline \multicolumn{2}{|l|}{ 10. ha wa bu } \\
\hline \multicolumn{2}{|l|}{ 11. wu ka wr } \\
\hline \multicolumn{2}{|l|}{ 12. pa u su } \\
\hline \multicolumn{2}{|l|}{ 13. wa pa sa } \\
\hline \multicolumn{2}{|l|}{ 14. ma poso } \\
\hline 15. tu wa so & \\
\hline
\end{tabular}

Tabel 3. Penanggalan prasasti Rumwiga I dan WT III 
Dari dua tabel tersebut di atas kita dapat menyimpulkan sementara bahwa WT III memiliki keakuratan pertanggalan yang sahih, meski diyakini jika citralekha WT III juga menyalin dari naskah lain. Maka secara umum meski masih sangat awal - penulisan pertanggalan dalam WT III yakni meliputi naik tahtanya seorang raja, wafatnya hingga sejumlah muatan historis dapat diyakini kesahihannya. Sementara untuk PRRBN kita tidak mempunyai data lain sebagai pembanding untuk menilai kebenaran angka tahun yang ditulis di dalam naskah.

Secara umum angka tahun yang ditunjukkan oleh PRRBN dan WT III dalam beberapa kasus memiliki angka yang sama, meski terdapat perbedaan angka tahun yang pada dasarnya memiliki selisih yang tidak terlampau jauh.

\section{Perbedaan nama tokoh dan gelar}

Perbedaan nama tokoh juga dijumpai antara WT III dan prasasti Mantyasih, meski demikian perbedaan tersebut dapat diketahui alasannya. Pada Prasasti Mantyasih nama-nama raja yang disebut adalah raja-raja yang pernah berkuasa penuh (dengan waktu yang cukup lama) atas tahta kerajaan Mataram Kuna. Penyebutan di dalam prasasti tersebut adalah ...rahyang ta rumuhun $r i$ mdang $r i$ poh pitu... dengan pelekatan gelar sebagai sri maharaja, sehingga sejumlah raja yang berkuasa hanya sebentar tidak ditulis di dalam prasasti Mantyasih. Di lain pihak di dalam WT III kita menemukan keseluruhan nama raja Mataram Kuna baik yang berkuasa penuh maupun tidak. Nama-nama raja tersebut ditulis dalam WT III adalah sebagai bentuk "historiografi" perubahan status sawah bagi sima di biara Pikatan semenjak Rakai Panangkaran hingga Rakai Watukura Dyah Balitung.

Jika perbedaan nama-nama raja dalam penulisan antara PRRBN dan WT III diyakini karena perbedaan agama - yang selanjutnya menimbulkan hipotesa dua wangsa - justru WT III mencatat hal lain meski secara eksplisit. Terlihat penganugerahan sawah yang didasari oleh alasan kekeluargaan juga diwarnai oleh alasan politik dan mungkin juga keagamaan. Kemungkinan besar biara di Pikatan yang didirikan oleh rahyangta i hara adalah biara agama Budha. Jika benar demikian, maka di dalam keluarga Sanjaya selain anaknya (Rakai Panangkaran) terdapat juga adiknya (rahyangta $i$ hara) yang juga menganut Budha (Kusen, 1988:4).

Secara umum ketiga naskah ini menyebut nama-nama raja yang identik, namun menariknya dalam PRRBN terdapat tiga tokoh raja yakni Sri Wirawairimattama, Samaratungga dan Pramodhawardhani yang disebut dalam daftar raja-raja. Ketiga tokoh tersebut merupakan tokoh sejarah yang diketahui namanya dalam prasasti Nalanda dan prasasti Kayumwungan. Ketiganya adalah bagian dari wangsa Sailendra (baca: beragama Budha). Baik di dalam WT III maupun Mantyasih ketiga tokoh tersebut tidak disinggung sama sekali bahkan perannya dalam penentuan status sawah bagi biara Pikatan pun tidak muncul dalam WT III. 
Selain itu, terlihat jika ketiga tokoh tersebut memiliki angka tahun berkuasa yang tumpang tindih dengan masa pemerintahan Panaraban hingga Garung apabila disesuaikan dengan WT III. Agaknya pencantuman tiga tokoh raja tersebut dapat dikaitkan dengan "hipotesis" yang ditulis dalam PRRBN yakni mengenai dua kerajaan atau kacakrawartyan yang pernah ada di Jawa tengah. Pertama, Jawa tengah bagian selatan yang dikuasai oleh dinasti Sailendra yang beragama Budha dan kedua Jawa tengah bagian utara yang dikuasai dinasti Sanjaya yang beragama Siwa. Namun sejauh ini data prasasti belum pernah dijumpai adanya pembagian semacam itu.

... Ikang ateher selendra wamsa haneng jawa madhya dumadi ratu kawasa // satuluynya i bhumi jawa madhya pinarwa dwa yatiku pantaranya / jawa madhya bang Iwar dumadi kacakrawartyan ning sanjaya wamsa / i sedeng jawa madhya bang kidul dumadi kacakrawartyan ing selendra wamsa //... (Atja, 1987: 144)

Demikian sebaliknya, di dalam PRRBN juga tidak disebutkan tokoh raja yang berkuasa dalam waktu singkat seperti Dyah Gula, Dyah Tagwas dan Rake Panumwangan Dyah Dewendra sebagaimana ditulis di dalam WT III. Meski demikian tiga tokoh tersebut juga merupakan tokoh sejarah yang pernah disebut di dalam prasasti Er Hangat (Dyah Tagwas), prasasti Poh Dulur (Dyah Dewendra).

Permasalahan lain yang muncul dari perbandingan antara PRRBN dan WT III adalah penyebutan nama lahir (garbha nama) sejumlah raja yang saling tidak sinkron serta penggunaan gelar-gelar kosmik dalam PRRBN yang belum pernah dijumpai dalam temuan prasasti. Untuk masalah nama lahir atau garbha nama dalam WT III didahului dengan partikel "dyah" yang kemungkinan besar adalah partikel penanda status sosial kebangsawanan, karena partikel semacam ini belum pernah dijumpai dalam nama diri rakyat kebanyakan. Dari garbha nama raja-raja yang dijumpai dalam WT III dijumpai fakta jika keseluruhan raja Mataram Kuna adalah berjenis kelamin pria (menganut sistem patriarkhi?). Selain itu garbha nama yang dijumpai dalam WT III juga menuliskan sejumlah garbha nama raja-raja yang sebelumnya tidak diketahui sama sekali seperti Dyah Jbang untuk Rake Wungkalhumalang, Dyah Manara untuk Rakai Warak serta Dyah Gula, Dyah Tagwas dan Dyah Dewendra yang tidak disebut dalam prasasti Mantyasih. Di dalam PRRBN kita melihat garbha nama yang tidak sama dengan WT III seperti,

\begin{tabular}{|c|c|c|c|c|}
\hline Rakai & \multicolumn{3}{|c|}{ PRRBN } & WT III \\
\hline $\begin{array}{l}\text { Warak } \\
\text { Pikatan }\end{array}$ & $\begin{array}{l}\text { Dyah Watukura } \\
\text { Dyah Kamulyan }\end{array}$ & & & $\begin{array}{l}\text { Dyah Manara } \\
\text { Dyah Saladu (pria) }\end{array}$ \\
\hline Gurunwangi & $\begin{array}{l}\text { Dyah Saladu } \\
\text { Ranumanggala }\end{array}$ & (wanita), & Dyah & Dyah Bhadra \\
\hline
\end{tabular}

Tabel 4. Perbandingan garbhanama PRRBN dan WT III 
Meski demikian di dalam WT III kita juga menjumpai berapa raja yang tidak disebut garbha namanya seperti Rakai Panangkaran, Rakai Panaraban dan Rakai Garung. Perbedaan garbha nama pada hakekatnya dapat menimbulkan interpretasi perbedaan personal. Dengan kata lain antara Rakai Warak, Pikatan dan Gurunwangi sebagaimana yang disebut di dalam PRRBN adalah tidak sama orangnya dengan Rakai Warak, Pikatan dan Gurunwangi yang disebut di dalam WT III.

Meski demikian di dalam sejarah kuna dijumpai adanya pergantian nama kerakaian tergantung dari kedudukan rakai yang baru, hal semacam ini terlihat di dalam sejumlah inskripsi pendek di candi Plaosan yang menulis Rakai Gurunwangi dengan garbhanama berbeda. Menurut Kusen (1991), persamaan nama kerakaian tersebut dapat terjadi jika ada raja yang naik tahta dengan jalan merebut kekuasaan kemudian dia menjalankan pemerintahan yang baru dari tempat baru sebagaimana terlihat dalam kasus Dyah Saladu. Rakai Pikatan Dyah Saladu sebelumnya menjabat rakai di Gurunwangi, setelah naik tahta sebagai raja dia berpindah tempat di daerah Pikatan. Sebenarnya dugaan bahwa para raja memerintah dari masing-masing daerah kerakaiannya belum mempunyai landasan yang kuat dan masih perlu dibuktikan kebenarannya (Kusen, 1991:2). Dengan kata lain antara Rakai Pikatan Dyah Saladu dan Rakai Gurunwangi Dyah Saladu adalah pribadi yang sama sebagaimana interpretasi inskripsi pendek Candi Plaosan. Namun suatu hal yang menarik adalah dituliskannya Dyah Saladu sebagai wanita atau rani di dalam PRRBN.

Permasalahan kedua yakni menyangkut gelar kosmik yang disandangkan PRRBN kepada Rakai Panunggalan/Panaraban, Rakai Warak dan Rakai Pikatan yang pada dasamya belum pernah dijumpai penyebutannya di dalam prasasti yang sejauh ini telah ditemukan. Selain itu beberapa nama raja beserta gelarnya yang ditulis dalam PRRBN memiliki kesamaan dengan prasasti-prasasti lain yang sebagian besar ditemukan akhir abad 19, sebagaimana terlihat di dalam tabel di bawah ini.

\begin{tabular}{|l|l|l|}
\hline \multicolumn{1}{|c|}{$\begin{array}{c}\text { Penyebutan dalam } \\
\text { PRRBN }\end{array}$} & \multicolumn{1}{c|}{$\begin{array}{c}\text { Penyebutan dalam } \\
\text { prasasti }\end{array}$} & \multicolumn{1}{c|}{$\begin{array}{c}\text { Dijumpai dalam } \\
\text { prasasti }\end{array}$} \\
\hline $\begin{array}{l}\text { Maharaja Tejahpurnapana } \\
\text { Panangkarana }\end{array}$ & tejahpurnna panamkarana ${ }^{2}$ & prasasti Kalasan \\
\hline Rakai Panunggalan & $\begin{array}{l}\text { Sri maharaja Rakai } \\
\text { panunggalan }\end{array}$ & prasasti Mantyasih I \\
\hline Rakai Warak & sri maharaja rakai warak & prasasti Mantyasih I \\
\hline $\begin{array}{l}\text { Dang Karayan Patapan Pu } \\
\text { Palar }\end{array}$ & $\begin{array}{l}\text { rakarayan patapan pu } \\
\text { palar }\end{array}$ & $\begin{array}{l}\text { prasasti } \\
\text { Kayumwungan }\end{array}$ \\
\hline $\begin{array}{l}\text { srimaharaja rakai } \\
\text { kayıwangi sri }\end{array}$ & $\begin{array}{l}\text { sri maharaja rake } \\
\text { kayuwangi sri }\end{array}$ & prasasti Ramwi \\
\hline
\end{tabular}

2 Sebelumnya dibaca sebagai maharajam dyah pancapanamkaranam yang kemudian di tahun 1950 dikoreksi pembacaannya oleh J.G Casparis menjadi tejahpurnna panamkarana

Berkala Arkeologi Tahun XXXX Edisi No. 1 / Mei 2010 


\begin{tabular}{|c|c|c|}
\hline sajjanotsawatungga & sajjanotsawatungga & \\
\hline rakai watumalang & haji rakai watu humalang & prasasti Panunggalan \\
\hline \multirow{2}{*}{$\begin{array}{l}\text { sri maharaja } \\
\text { iswarakesawotsawatungga }\end{array}$} & $\begin{array}{l}\text { rake watukura dyah } \\
\text { balitung sri iswara } \\
\text { kesawasamarotungga }\end{array}$ & prasasti Kinewu \\
\hline & $\begin{array}{l}\text { rake watukura dyah } \\
\text { balitung sri } \\
\text { iswarakesawotsawatungga }\end{array}$ & prasasti Watukura A \\
\hline
\end{tabular}

Tabel 5. Perbandingan gelar kosmik dalam PRRBN dengan prasasti lain

\begin{tabular}{|l|l|}
\hline \multicolumn{1}{|c|}{ Rakai } & \multicolumn{1}{c|}{ Gelar } \\
\hline $\begin{array}{l}\text { Rakai } \\
\text { Panunggalan }\end{array}$ & $\begin{array}{l}\text { Haji Rakai Panunggalan Lingganagarotama/Prabu Dyah } \\
\text { Panunggalan Bimaparakrama Linggapawitra } \\
\text { Yawabhumandala }\end{array}$ \\
\hline Rakai Warak & Haji Warak Linggottama Satya Jayabhumi \\
\hline Rakai Pikatan & Sang Prabhu Linggeswara Sakalabhumandala \\
\hline $\begin{array}{l}\text { Rakai } \\
\text { Kayuwangi }\end{array}$ & Sri maharaja Kayuwangi tunggal kawasa Sakalabbhumi \\
\hline
\end{tabular}

Tabel 6. Sejumlah gelar kosmik yang belum terklarifikasi dalam prasasti

\section{Perbedaan muatan historis (yang tersurat dan tersirat)}

Dengan berpedoman bahwa WT III lebih otentik muatan historisnya (didasarkan penanggalan yang lengkap serta masa penulisan yang hanya bertaut tidak lebih 162 tahun), kita dapat memperoleh hasil sementara khususnya mengenai daftar raja-raja Mataram kuna. Dari perbandingan informasi historis yang terkandung baik di dalam PRRBN dan WT III diperoleh beberapa simpulan penting sebagai berikut.

a. Dalam PRRBN terlihat jika suksesi antar raja tidak dideskripsikan dengan terang bahkan cenderung tidak ada sisi negatif. Hal ini terbukti dari cara mendeskripsikan yang normatif-kronologis para raja yang berkuasa. Namun apabila dibandingkan dengan WT III kita justru menjumpai adanya upaya penggantian secara tidak wajar (penggulingan) atas tahta raja yang sah.

b. PRRBN tidak menyebut fakta historis yang sangat penting seperti kekosongan tahta hampir selama 7 tahun yakni dari masa raja Rakai Garung hingga raja Rakai Wungkalhumalang yang dalam WT III ditulis sebagai ... anayaka ing rat rikang kala ... Selain itu juga dijumpainya informasi historis tentang adanya raja yang minggat dari kraton setelah sebulan berkuasa.

c. Tokoh nomor 14 (Tabel 1) dalam WT III (Rake Gurunwangi Dyah Bhadra) dan PRRBN (Rani Gurunwangi Dyah Saladu) menunjuk 2 pribadi yang berbeda, yakni terlihat pada perbedaan garbhanama. Selain itu perbedaan juga terlihat pada angka tahun berkuasa. Di WT III tokoh raja (Rakai Gurunwangi) disebut hanya berkuasa selama 1 bulan 
lantas keluar dari kraton (minggat), sedangkan di PRRBN (Rani Gurunwangi) disebut berkuasa hingga 4 tahun. Fakta ini semakin diperkuat dengan daftar raja-raja dalam prasasti Mantyasih yang juga tidak menyebut nama Rakai Gurunwangi Dyah Bhadra berhubung masa pemerintahannya hanya sebentar.

d. Keseluruhan raja-raja Mataram Kuna sebagaimana ditulis di dalam WT III adalah berjenis kelamin lelaki. Sedangkan di PRRBN disebutkan adanya seorang raja wanita yakni Rani Gurunwangi Dyah Saladu.

e. Penyebutan tokoh Wirawairimathana, Samaratungga dan Pramodhawardhani dalam urutan raja-raja Mataram Kuna dalam PRRBN nampaknya tidak didukung oleh fakta dalam WT III (dan Mantyasih), meski masing-masing tokoh tersebut adalah tokoh historis.

\section{KI PURBANAGARA DAN SANG CITRALEKHA: DARI MANAKAH MEREKA MEMPEROLEH DATA?}

Dari keseluruhan uraian di atas muncul satu pertanyaan penting, yakni dari manakah Ki Purbanagara memperoleh "data" tentang sejarah Mataram Kuna (baca: Raja-Raja Mataram Kuna)? Serta dari manakah sang citralekha WT III mengutip sejarah raja-raja Mataram Kuna?

Proses kutip-mengutip dalam WT III terlihat dari prasasti zaman Rake Garung dari tahun 721 Saka yang dikutip dengan sadar oleh sang citralekha ... nahan prasasti rake garung ... (demikianlah prasasti Rake Garung). Logis apabila citralekha juga menggunakan data lain (lontar maupun prasasti logam lain) yang berisi "data" raja-raja untuk kemudian dirangkumnya dalam tembaga WT III.

Dalam PRRBN memang disebutkan adanya sumber-sumber tertulis lain yang berupa naskah kuna, tulisan-tulisan riwayat, cerita raja kuasa, naskah kebijakan raja, ilmu tatanegara, naskah berbagai keluarga milik mahakawi dan raja dari beberapa wilayah, prasasti dan tulisan-tulisan piagam. Namun kesemuanya tidak disebut di mana sumber-sumber tertulis tersebut diambil serta di manakah lokasi pengambilannya. Berikut petikan PRRBN teks halaman 4 dan 5 sebagaimana telah ditransliterasikan oleh Atja (1987:59).

...punwwa pustaka / serat-serat katha / itihasa raja kawasa / pustaka rajaniti / pustaka rajyaniti / pustaka gotrasawala / drewya ning sang mahakawi mwang raja sakeng pirang sakeng mandalekang....kumwa juga nitisastra/serat-serat prasasti...

Penyebutan prasasti beserta piagam-piagam dalam proses pencarian data PRRBN tersebut sangat menarik. Karena sebagian besar tokoh-tokoh raja yang disebut dalam PRRBN hampir keseluruhan identik dengan prasasti Mantyasih I yakni terlihat dari penulisan nama raja urutan ketiga yakni Rakai Panunggalan, serta ketiadaan tiga tokoh raja Dyah Gula, Dyah Tagwas, Dyah Dewendra, dan Dyah Bhadra. Dengan kata lain Ki Purbanagara menggunakan sumber yang berbeda dengan sumber tertulis 
yang dipakai sang citralekha dari WT III di dalam mendeskripsikan kronologis keseluruhan raja-raja yang berkuasa di Mataram Kuna (Jawa Tengah khususnya). Selain itu, PRRBN agaknya menggunakan sumber lain yang menyebutkan tokoh Wirawairimattama, Samaratungga dan Pramodhawardhani sebagai raja yang pernah berkuasa di Mataram Kuna. Dimana ketiga tokoh tersebut justru tidak tertulis dalam daftar raja-raja yang dijumpai di prasasti WT III dan Mantyasih I.

Tokoh utama sebagai "pengumpul data" dalam PRRBN adalah $\mathrm{Ki}$ Purbanagara. Dia adalah salah seorang dari saptadhyaksa yang bertugas mencari dan mengambil bermacam-macam tulisan dari beberapa negara. Dia mendapat tugas demikian karena memiliki pengetahuan tentang riwayat masa lampau berkaitan dengan berdiri dan musnahnya suatu kerajaan di Nusantara (Atja, 1987:17). Namun untuk WT III kita tidak mengetahui siapakah penulisnya (penatah di logam maupun penulis di atas daun), namun yang jelas sang citralekha dengan jujur menyatakan bahwa ia telah mengutip utuh prasasti dari jaman Rakai Garung. Dengan demikian, bisa diyakini jika sang citralekha juga menggunakan prasasti lain dari masa yang lebih tua untuk dirangkum dan ditulis kembali di dalam prasasti tembaga WT III.

Naskah-naskah yang ditulis di atas bahan organik seperti kayu, daluang, tanduk, kulit binatang dan bambu pada umumnya berumur tidak panjang karena iklim tropis Indonesia. Namun pada kasus-kasus yang sangat jarang justru naskah di atas bahan organik terawetkan dengan baik. Keawetan tersebut disebabkan oleh faktor manusia serta metode penyimpanannya. Manusia dalam upaya pelestarian naskah layaknya pisau bermata dua! Sejarah mencatat sejumlah naskah-naskah tua turut pula dihancurkan selama masa peperangan. Hal ini lebih dipengaruhi oleh perbedaan pandangan ideologis-dogmatis. Dapat diambil contoh adalah penghancuran naskah Batak (pustaha) pada masa perang Padri maupun oleh para Misionaris (Kozok, 2006:43). Di lain pihak, manusia juga memiliki adat yang menjujung tinggi pusaka leluhur, termasuk di dalamnya naskah leluhur. Dengan demikian naskah akan lebih terselamatkan dari kehancuran. Penyimpanan naskah pusaka dilakukan dengan seksama. Semua barang pusaka pada umumnya dibalut dengan kain dan disimpan di dalam sebuah peti kayu. Bila disimpan semacam itu maka pusaka akan terlindung dari matahari yang bersifat merusak. Selain itu pada umumnya pusaka diletakkan di atas loteng rumah, selain sebagai bentuk penghormatan tanpa disadari jika kelembaban udara di loteng relatif lebih rendah. Contoh kasus semacam ini adalah naskah Tanjung Tanah dari Kerinci yang berasal dari abad 13 Masehi yakni adanya penyebutan Dharmasraya, serta kain dari Sulawesi yang juga berasal dari abad 13 Masehi (Kozok, 2006:44).

Sumber-sumber tertulis sebagaimana yang dikumpulkan $\mathrm{Ki}$ Purbanagara dari berbagai wilayah di Nusantara tentunya adalah karya (naskah sastra dan hukum) yang berasal dari kurun waktu sebelum abad ke-17. Beberapa ciri naskah sebelum abad ke-18 sebagaimana kesimpulan 
dari Ricklefs atas studinya terhadap Babad Sengkala (1738) dapat dipakai sebagai gambaran umum bagaimana keadaan naskah (dan teks) pada waktu itu. Berikut adalah ciri naskah pra abad ke-17(Ekadjati,2005c:263),

1. Pengetahuan tentang Jawa Kuna masih tampak hidup dipelajari secara lisan dan tulisan di lingkungan kraton hingga tahun 1730-an. Sesudah tahun-tahun tersebut mulai terjadi proses kemunduran dan periode tahun 1770-an pengetahuan tersebut sudah hilang.

2. Adanya tradisi penulisan sejarah yang akurat di lingkungan kraton Jawa paling sedikit sampai dengan akhir abad ke-17 Masehi.

3. Adanya kebiasaan memelihara tradisi bersejarah yang akurat sampai tahun 1730-an

4. Kronik-kronik yang berasal dari akhir abad ke-18, terutama abad ke-19 dan awal abad ke-20 sudah kurang akurat lagi.

Untuk pernaskahan di dunia Melayu kehadiran bahasa Melayu telah mengalami perkembangan yang cukup panjang, ditilik dari temuan prasasti berbahasa Melayu dari abad ke-7 dari masa Sriwijaya. Karya sastra masa itu kemungkinan masih diabdikan bagi kepentingan agama dan diperkirakan masih hidup di dalam lingkungan kerajaan. Sementara sastra di luar kerajaan (umum) tidak ada deskripsi sama sekali.

Dari perbandingan penggal cerita raja-raja Mataram Kuna antara PRRBN dan WT III dapat diketahui jika keakuratan fakta (khususnya pertanggalan) dari PRRBN ternyata lemah apabila dibandingkan dengan WT III serta kehadiran fakta historis yang dijumpai di dalam WT III namun tidak termuat di dalam PRRBN. Meski demikian, kita harus tetap berprasangka baik terhadap eksitensi PRRBN, karena hingga saat ini kita masih berhadapan dengan sumber-sumber tertulis lain (naskah dan prasasti) yang belum sampai ke tangan kita kembali. Kemungkinan besar naskah atau prasasti tersebut merupakan referensi utama di masa lalu dalam proses penyalinan (pengutipan) ulang.

PRRBN masih sangat layak dijadikan kajian filologis melalui komparasi dengan sejumlah data otentik lain. Informasi tentang masa prasejarah Indonesia hingga masa kerajaan Nusantara kuna yang disebutkan dalam PRRBN perlu diperbandingkan secara kritis dengan data lain yang relevan.

Sebagai penutup, perlu diungkap kembali pemyataan Bambang Purwanto: "Ketika sastra dan sejarah dibicarakan secara bersama-sama segera muncul pertanyaan, apakah ada fiksi di dalam sejarah dan apakah ada fakta di dalam sastra". Tulisan ini telah berusaha membicarakan secara bersama-sama antara sastra dan sejarah yakni dengan mensintesiskan "fakta sejarah" antara sastra (PRRBN) dan sejarah (WT III), namun hasil yang diperoleh masih jauh dari memuaskan.

Surakarta, Juli 2010

Nahan hingan iking katha wiwaksan 


\section{KEPUSTAKAAN}

Atja dan Edi S. Ekadjati, 1987, Pustaka Rajya Rajya i Bhumi Nusantara, Suntingan Naskah dan Terjemahan, Bandung: Departemen Pendidikan dan Kebudayaan

Atja, 2005, "Beberapa Catatan Tentang Tanggapan Terhadap Pustaka Karya Pangeran Wangsakerta, dalam Polemik Naskah Wangsakerta, Jakarta: Pustaka Jaya

Ayatrohaedi dan Atja, 1991, Pustaka Rajya Rajya i Bhumi Nusantara Panwa 2 Sargah 4, Sebuah Naskah Sastra-Sejarah Karya Kelompok Kerja di Bawah Tanggungjawab Pangeran Wangsakerta, Jakarta: Departemen Pendidikan dan Kebudayaan

Dwiyanto, Djoko, 1986, "Pengamatan Terhadap Data Kesejarahan Dari Prasasti Wanua Tengah III Tahun 809 M", dalam Pertemuan IImiah Arkeologi IV, Jakarta, 1986

Ekadjati, Edi. S, 2005a, "Sekitar Naskah Pangeran Wangsakerta", dalam Polemik Naskah Wangsakerta, Jakarta: Pustaka Jaya

2005b, "Pustaka Rajya Rajya i Bhumi Nusantara, Sebuah Historiografi Tradisional", dalam Polemik Naskah Wangsakerta, Jakarta: Pustaka Jaya

2005c, "Sekali Lagi Sekitar Naskah Wangsakerta", dalam Polemik Naskah Wangsakerta, Jakarta: Pustaka Jaya

Kozok, Uli, 2006, Kitab Undang-Undang Tanjung Tanah Naskah Melayu yang Tertua, Jakarta: Yayasan Obor Indonesia

Kusen, 1988, "Faktor-Faktor Terjadinya Perubahan Status Sawah di Wanua Tengah Dalam Masa Pemerintahan Raja-Raja Mataram Kuna Abad 8-10", Laporan Penelitian, Yogyakarta: Fakultas Sastra Universitas Gadjah Mada

1991, "Identifikasi Toponim Dalam Prasasti Jawa Kuna Abad IX-X Dari Prambanan dan Sekitarnya Dengan Toponim Masa Kini", Laporan Penelitian, Yogyakarta: Fakultas Sastra Universitas Gadjah Mada

Lubis, Nina H., 2002, "Kontroversi Tentang Naskah Wangsakerta", dalam Humaniora volume XIV/I. No.1, Yogyakarta: Fakultas IImu Budaya Universitas Gadjah Mada 
Purwanto, Bambang, 2006, Gagalnya Historiografi Indonesiasentris?!, Yogyakarta: Penerbit Ombak

Soeratno,1994, "Variasi sebagai Bentuk Kreativiti Pengarang Kedua dalam Dunia Sastera Melayu" dalam Pengarang dan Kepengarangan Melayu, Kuala Lumpur: Dewan Bahasa dan Pustaka

Sudibyo, 1999, "Bukan Dua Sisi dari Sekeping Mata Uang Pernaskahan dan Perteksan dalam Tradisi Sastra Melayu Klasik", dalam Humaniora volume XI, Yogyakarta: Fakultas IImu Budaya Universitas Gadjah Mada

Wurjantoro, Edhie, 1995, "Pertanggalan Prasasti (Kajian Prasasti Abad VIIIX M)", dalam Kirana, Jakarta: PT.Intermasa

Zoetmulder, P.J, 1994, Kalangwan A Survey of Old Javanese Literature, diindonesiakan oleh Dick Hartoko, Kalangwan Sastra Jawa Kuno Selayang Pandang, Jakarta: Penerbit Djambatan 